\title{
Reaction of Cowpea Genotypes for Stemfly Ophiomyia phaseoli (Tryon) Diptera: Agromyzidae Infestation
}

\author{
Mantesh Soratur, K.S. Jagadesh, D. Devika Rani*, \\ T.G. Avinash and Shiva Murthy Naik
}

UAS, GKVK, Bengaluru, Karnataka, India

*Corresponding author

\section{A B S T R A C T}

\begin{tabular}{|l|}
\hline Key w or d s \\
Cowpea genotype, \\
stemfly, Ophiomyia \\
phaseoli
\end{tabular}

An experiment was conducted on screening of germ plasm against stemfly of cow pea (Vigna unguiculata L.) under randomized block design at student farm, university of Agricultural sciences, Bengaluru during rabi, 2016-17. The objective of this study was to investigate the most effective germ plasm type against the stem fly that is Ophiomyia phaseoli population. The highest number of eggs recorded in PGCP -13 . The lowest number of feeding punctures was seen in C -152 and the genotype PGCP - 13, where the highest number of punctures was observed. Lowest number of maggots were seen in KM 5 and KBC -2 except PGCP -5 and PGCP -13 . The highest number of pupae recorded in PGCP -5 . The lowest tunnel length was observed in $\mathrm{KBC}-8$ and highest tunnel length was noticed in PGCP -13 . The yield of ten plant per entries also differed significantly, it was highest in $\mathrm{KBC}-2$ and lowest yield was noticed in PGCP - 3 .

\section{Introduction}

Among the various grain legumes, cowpea [Vigna unguiculata (L.) Walp.] is one of the most important pulse crop in Karnataka, where it is cultivated over an area of 0.87 lakh hectares with a production of 0.35 lakh tonnes and the productivity of $406 \mathrm{~kg} / \mathrm{ha}$ (anon 20122013). The cowpea grain contains an average of 23-25 percent proteins, 50-67 percent carbohydrates, fat 1.3 percent and fibre 1.6 percent and 8-9percent of water (Pai, 1990). It is luxuriously growing crop which attracts insect pests and poses serious threat to its production. Cowpea is infested by 21 insect pests (Karungi et al., 2000) of which agromyzid stem fly, Ophiomyia phaseoli, is a serious pest in cowpea growing states of India, due to its destructive feeding habits on cortical region of the stem, right from the unfoliage part of the stem.

\section{Materials and Methods}

\section{Incidence of stem fly on cowpea}

To study the incidence of stem fly the feeding punctures by the adults, oviposition punctures were recorded on 20 randomly selected plant samples at weekly intervals 7 days after 
germination (DAG) from four subplots. The number of maggots, pupae, total length of plant from base to growing tip of the stem and tunnelled length by the stem fly was recorded.

\section{Screening of selected genotypes against} major insect pests

Ten genotypes viz., KM-5, KBC-2, KBC-8, KBC-9, C-152, PGCP-3, PGCP-5, PGCP-6, PGCP-13 and IT-38956-1 were screened for the reaction to different pests of cowpea. Each genotype was sown in two rows spacing of three meter length. Each genotype was sown in three replications and randomized. The genotypes were sown during the $17^{\text {th }}$ August, 2016. Recommended cultural practices were followed for raising the crop except for the plant protection measures.

\section{Screening of cowpea genotypes for resistance to stem fly}

For stem fly screening the genotypes were screened during third week after sowing. Fifteen plants were selected randomly (five plants destructive sampling was made to record the observations:

\section{Incidence of stemfly}

The stem fly infestation started right from the seedling stage of the crop (Table1).

\section{Ovipositional punctures}

After the first week of sowing i.e. August $3^{\text {rd }}$ week $\left(34^{\text {th }} \mathrm{MW}\right)$ the numbers of ovipositional punctures were i.e. (2.15eggs/five leaves). It started upto third week $\left(35^{\text {th }} \mathrm{MW}\right)$ were maximum number of ovipositional punctures were recorded (2.25eggs/five leaves). Then the number of ovipositional punctures decreased, after the $4^{\text {th }}$ week of sowing $\left(37^{\text {th }}\right.$ $\mathrm{MW}$ ), there were no ovipositional punctures observed one month after the crop sowing.

\section{Feeding punctures}

The number of feeding punctures was seen throughout the crop growth stage but the maximum number of feeding punctures was recorded in the seedling stage of the crop i.e. (155.65/five leaves) at $37^{\text {th }}$ standard meteorological week.

\section{Number of maggots}

Maggot's population was seen during the second week of sowing i.e. August $4^{\text {th }}$ week $\left(35^{\text {th }} \mathrm{MW}\right) 2.10$ maggots/plant and increased upto 3.45 maggots per plant during the third week after sowing $\left(36^{\text {th }} \mathrm{MW}\right)$.

The maggots population was recorded throughout the reproductive stage of crop but numbers were very negligible.

\section{Number of Pupae}

The pupal count per plant was also recorded where the pupae were observed at the third week after sowing i.e. September $1^{\text {st }}$ week ( $\left.36^{\text {th }} \mathrm{MW}\right)$ i.e., 0.15 pupae per plant.

The highest number of pupae per plant recorded during the fifth week after sowing $\left(35^{\text {th }} \mathrm{MW}\right)$ i.e., 2.95 pupae per plant. The pupal count per plant was also recorded through the crop growth stage.

\section{Percent tunneling}

The total plant length of the genotypes did not differ significantly among the genotypes but tunnel length varied significantly among the genotypes.

It varied from 5.88 to $9.29 \mathrm{~cm}$. The lowest tunnel length was observed in KBC-8 (5.88) which is on par with KBC-9, C152 and PGCP 6 . The highest tunnel length was noticed in PGCP-13. 


\section{Results and Discussion}

The number of eggs laid was significantly different among the entries. The number of eggs laid per five leaves varied from 0.00 to 1.50 eggs. No eggs were recorded in PGCP -6 which was on par with $\mathrm{KBC}-9, \mathrm{KBC}-8$, $\mathrm{KBC}-2$ and $\mathrm{C}-152$. The highest number of eggs recorded in PGCP - 13 (1.50). The number of feeding punctures per 5 leaves also varied significantly among the entries ranging from 128.17 to 269.50 (Table 1). The lowest number of feeding punctures seen in $\mathrm{C}-152$ (128.17), which was on par with all entries except the genotype PGCP - 13, where the highest number of punctures (269.50) were observed. The number of maggots per plant also varied significantly among all the entries. Lowest number of maggots was seen in KM 5 (0.13) and KBC - 2 (0.13) which were on par with all other genotypes, except PGCP -5 and PGCP -13 . Where in the number of maggots were 1.67 and 1.61 respectively. The number of pupae per plant also varied significantly among all the entries. Lowest number of pupae was seen in 0.33 to 3.15. The lowest number of pupae seen in KM - 5 (0.33), KBC -9 (0.33) and $\mathrm{C}-152$ which is on par with $\mathrm{KBC}-2, \mathrm{KBC}-8$, PGCP -6 and IT- 38956, whereas highest number of pupae recorded in PGCP -5 . The total plant length of the genotypes did not differ significantly among the genotypes but tunnel length varied significantly among the genotypes. It varied from 5.88 to $9.29 \mathrm{~cm}$. The lowest tunnel length was observed in KBC - 8 (5.88) which is on par with $\mathrm{KBC}-9, \mathrm{C}-152$, PGCP -6 . The highest tunnel length was noticed in PGCP - 13. The yield of ten plant per entries also differed significantly, it was highest in $\mathrm{KBC}-2$ (19.61gms), PGCP - 6 (19.62 gms), $\mathrm{KBC}-8$ (19.53gms), KM - 5 (19.26 gms). The lowest yield was noticed in PGCP - 3 (15.86gms).

Table.1 Incidence of stem fly during, Kharif 2016

\begin{tabular}{|c|c|c|c|c|c|c|}
\hline $\begin{array}{l}\text { Met } \\
\text { wk. }\end{array}$ & Weeks & $\begin{array}{l}\text { Ovipositional } \\
\text { Punctures/ } \\
\text { 5leaves }\end{array}$ & $\begin{array}{c}\text { Feeding } \\
\text { Punctures/ } \\
\text { 5leaves }\end{array}$ & $\begin{array}{l}\text { No. of maggots } \\
\text { /plant }\end{array}$ & $\begin{array}{l}\text { No. of pupae } \\
\text { /plant }\end{array}$ & $\begin{array}{l}\text { Percent } \\
\text { tunneling }\end{array}$ \\
\hline 34 & 24-08-2016 & 2.15 & 45.55 & 0.00 & 0.00 & 81.52 \\
\hline 35 & $31-08-2016$ & 2.22 & 64.30 & 2.10 & 0.00 & 76.53 \\
\hline 36 & 07-09-2016 & 1.10 & 60.75 & 3.40 & 0.15 & 64.33 \\
\hline 37 & 14-09-2016 & 0.20 & 155.65 & 1.30 & 1.45 & 54.41 \\
\hline 38 & 21-09-2016 & 0.00 & 119.55 & 0.35 & 2.95 & 55.58 \\
\hline 39 & 28-09-2016 & 0.00 & 106.10 & 0.25 & 1.25 & 58.01 \\
\hline 40 & 05-10-2016 & 0.00 & 90.15 & 0.00 & 0.35 & 48.43 \\
\hline 41 & $12-10-2016$ & 0.00 & 57.35 & 0.00 & 0.20 & 43.25 \\
\hline 42 & 19-10-2016 & 0.00 & 55.10 & 0.00 & 0.20 & 43.39 \\
\hline 43 & 26-10-2016 & 0.00 & 57.90 & 0.15 & 0.20 & 45.44 \\
\hline 44 & 02-11-2016 & 0.00 & 48.15 & 0.05 & 0.35 & 44.89 \\
\hline 45 & 09-11-2016 & 0.00 & 56.65 & 0.00 & 0.10 & 44.82 \\
\hline 46 & $16-11-2016$ & 0.00 & 50.48 & 0.00 & 0.30 & 43.84 \\
\hline
\end{tabular}


Table.2 Screening of cowpea genotypes against stem fly

\begin{tabular}{|c|c|c|c|c|c|c|c|c|}
\hline SI No. & Genotypes & $\begin{array}{c}\text { Egg } \\
\text { punctures/ } 5 \\
\text { leaves }\end{array}$ & $\begin{array}{c}\text { Feeding } \\
\text { punctures/5leave } \\
\text { s/plant }\end{array}$ & $\begin{array}{c}\text { No. of } \\
\text { maggots/ } \\
\text { plant }\end{array}$ & $\begin{array}{c}\text { No. of } \\
\text { pupae/plant }\end{array}$ & $\begin{array}{c}\text { Total } \\
\text { length of } \\
\text { plant }\end{array}$ & $\begin{array}{c}\text { Tunnel } \\
\text { length of } \\
\text { plant }\end{array}$ & $\begin{array}{l}\text { Yield of } 10 \\
\text { labelled plants (in } \\
\text { grams) }\end{array}$ \\
\hline 1 & $\begin{array}{l}\text { KM-5 } \\
\text { (check) }\end{array}$ & $\begin{array}{l}0.33^{\mathrm{a}} \\
(0.91)\end{array}$ & $\begin{array}{c}170.3^{\mathrm{a}} \\
(12.80)\end{array}$ & $\begin{array}{c}0.13^{\mathrm{a}} \\
(0.79)\end{array}$ & $\begin{array}{c}0.33^{\mathrm{a}} \\
(0.91)\end{array}$ & $\begin{array}{l}11.89 \\
(3.52)\end{array}$ & $\begin{array}{l}7.05^{a b} \\
(2.75)\end{array}$ & $19.26^{e}$ \\
\hline 2 & KBC-2 & $\begin{array}{c}0.27^{\mathrm{a}} \\
(0.87)\end{array}$ & $\begin{array}{l}142.87^{a} \\
(11.90)\end{array}$ & $\begin{array}{c}0.13^{\mathrm{a}} \\
(0.79)\end{array}$ & $\begin{array}{c}0.40^{\mathrm{a}} \\
(0.94)\end{array}$ & $\begin{array}{l}10.65 \\
(3.33)\end{array}$ & $\begin{array}{l}7.01^{a b} \\
(2.73)\end{array}$ & $19.61^{e}$ \\
\hline 3 & $\mathrm{KBC}-8$ & $\begin{array}{c}0.18^{\mathrm{a}} \\
(0.82)\end{array}$ & $\begin{array}{l}167.09^{a} \\
(12.76)\end{array}$ & $\begin{array}{c}0.22^{a} \\
(0.83)\end{array}$ & $\begin{array}{l}1.04^{\mathrm{a}} \\
(1.21)\end{array}$ & $\begin{array}{l}10.30 \\
(3.28)\end{array}$ & $\begin{array}{l}5.88^{\mathrm{a}} \\
(2.52)\end{array}$ & $19.53^{\mathrm{e}}$ \\
\hline 4 & KBC-9 & $\begin{array}{c}0.13^{\mathrm{a}} \\
(0.79)\end{array}$ & $\begin{array}{l}157.20^{\mathrm{a}} \\
(12.53)\end{array}$ & $\begin{array}{c}0.27^{\mathrm{a}} \\
(0.86)\end{array}$ & $\begin{array}{c}0.33^{\mathrm{a}} \\
(0.91)\end{array}$ & $\begin{array}{l}10.62 \\
(3.31)\end{array}$ & $\begin{array}{l}5.96^{\mathrm{a}} \\
(2.53)\end{array}$ & $19.11^{\mathrm{de}}$ \\
\hline 5 & C-152 & $\begin{array}{c}0.27^{\mathrm{a}} \\
(0.87)\end{array}$ & $\begin{array}{l}128.17^{\mathrm{a}} \\
(11.34)\end{array}$ & $\begin{array}{c}0.40^{\mathrm{a}} \\
(0.93)\end{array}$ & $\begin{array}{c}0.33^{\mathrm{a}} \\
(0.91)\end{array}$ & $\begin{array}{c}9.17 \\
(3.11)\end{array}$ & $\begin{array}{l}5.99^{\mathrm{a}} \\
(2.54)\end{array}$ & $18.02^{\mathrm{cd}}$ \\
\hline 6 & PGCP-3 & $\begin{array}{l}1.13^{\mathrm{c}} \\
(1.25)\end{array}$ & $\begin{array}{l}159.60^{\mathrm{a}} \\
(12.63)\end{array}$ & $\begin{array}{c}1.33^{b} \\
(1.34)\end{array}$ & $\begin{array}{l}2.13^{b c} \\
(1.59)\end{array}$ & $\begin{array}{c}9.77 \\
(3.20)\end{array}$ & $\begin{array}{l}7.31^{a b} \\
(2.79)\end{array}$ & $15.86^{\mathrm{a}}$ \\
\hline 7 & PGCP-5 & $\begin{array}{l}1.07^{b c} \\
(1.21)\end{array}$ & $\begin{array}{l}193.50^{\mathrm{a}} \\
(13.85)\end{array}$ & $\begin{array}{l}1.67^{b} \\
(1.45)\end{array}$ & $\begin{array}{l}3.15^{c} \\
(1.91)\end{array}$ & $\begin{array}{l}10.10 \\
(3.26)\end{array}$ & $\begin{array}{l}8.22^{b c} \\
(2.95)\end{array}$ & $16.33^{\mathrm{ab}}$ \\
\hline 8 & PGCP-6 & $\begin{array}{c}0.00^{\mathrm{a}} \\
(0.71)\end{array}$ & $\begin{array}{l}134.47^{\mathrm{a}} \\
(11.61)\end{array}$ & $\begin{array}{c}0.40^{\mathrm{a}} \\
(0.92)\end{array}$ & $\begin{array}{c}0.53^{\mathrm{a}} \\
(1.00)\end{array}$ & $\begin{array}{c}9.49 \\
(3.15)\end{array}$ & $\begin{array}{c}6.16^{\mathrm{a}} \\
(2.57)\end{array}$ & $19.62^{e}$ \\
\hline 9 & PGCP-13 & $\begin{array}{l}1.50^{c} \\
(1.41)\end{array}$ & $\begin{array}{l}269.50^{b} \\
(16.42)\end{array}$ & $\begin{array}{l}1.61^{b} \\
(1.45)\end{array}$ & $\begin{array}{l}1.20^{\mathrm{ab}} \\
(1.28)\end{array}$ & $\begin{array}{l}11.74 \\
(3.50)\end{array}$ & $\begin{array}{l}9.29^{c} \\
(3.13)\end{array}$ & $17.39^{\mathrm{bc}}$ \\
\hline 10 & IT-38956-1 & $\begin{array}{l}0.38^{a b} \\
(0.94)\end{array}$ & $\begin{array}{l}154.42^{a} \\
(12.35)\end{array}$ & $\begin{array}{c}0.47^{\mathrm{a}} \\
(0.97)\end{array}$ & $\begin{array}{c}1.20^{\mathrm{a}} \\
(1.25)\end{array}$ & $\begin{array}{l}11.61 \\
(3.47)\end{array}$ & $\begin{array}{l}6.95^{a b} \\
(2.73)\end{array}$ & $18.42^{\mathrm{cd}}$ \\
\hline \multicolumn{2}{|c|}{ F test } & 5.56 & 4.02 & 8.12 & 6.26 & 1.18 & 4.15 & 11.87 \\
\hline \multicolumn{2}{|c|}{$\mathrm{SE} \mathrm{m} \pm$} & 0.10 & 0.72 & 0.10 & 0.13 & - & 0.10 & 0.40 \\
\hline \multicolumn{2}{|c|}{$\mathrm{CD}(\mathrm{p}=0.05)$} & 0.29 & 2.15 & 0.28 & 0.40 & - & 0.29 & 1.20 \\
\hline \multicolumn{2}{|c|}{ CV (\%) } & 17.24 & 9.76 & 15.96 & 19.60 & - & 6.19 & 3.81 \\
\hline
\end{tabular}

Note: Figures in the parentheses are $\sqrt{x}+0.5$ transformed values. In vertical columns, means followed by similar alphabets are not different statistically $(0.05)$ as per DMRT 
Fig.1 Incidence of stem fly, O. phaseoli

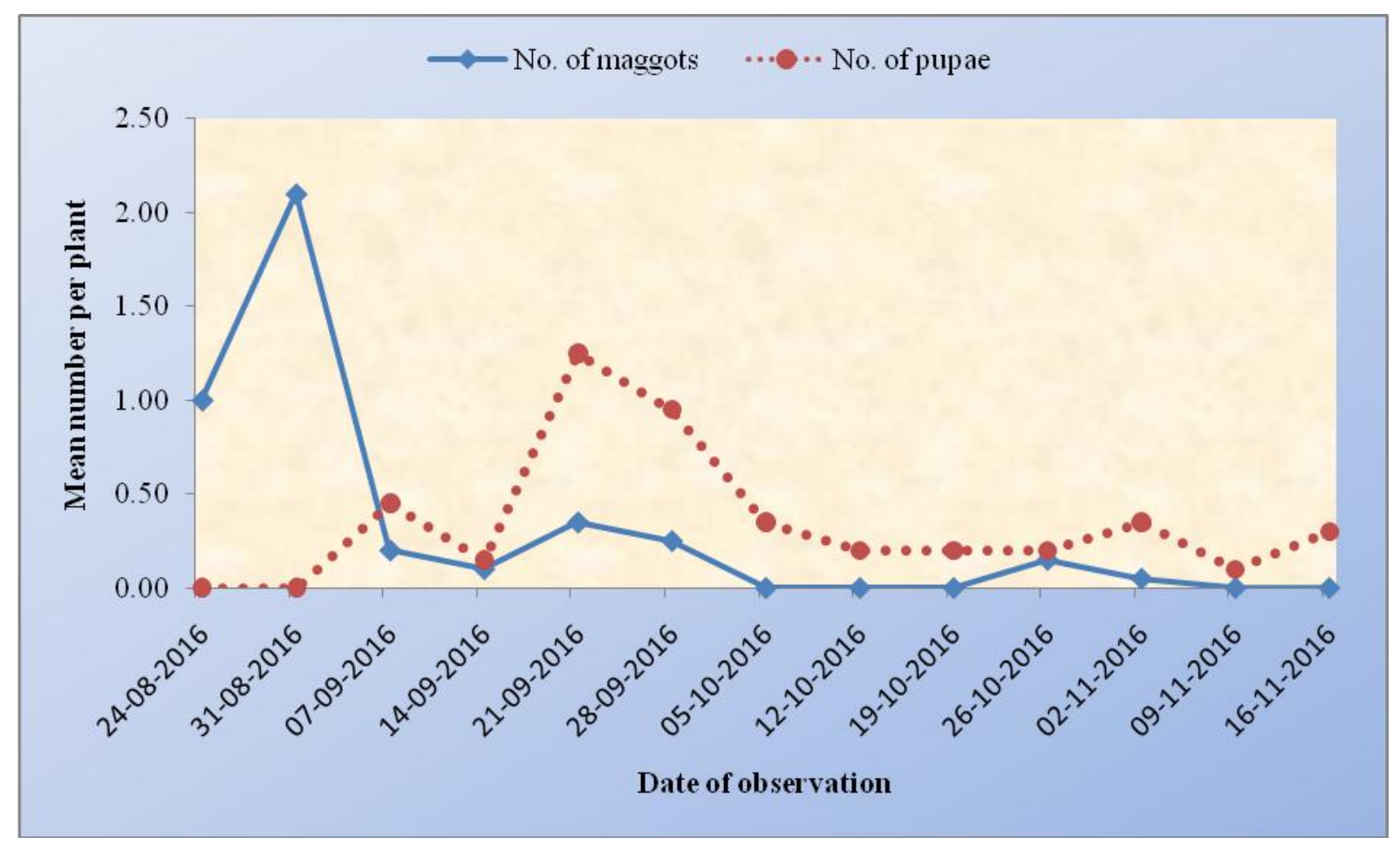

Fig.2 Reaction of cowpea genotypes to stem fly infestation

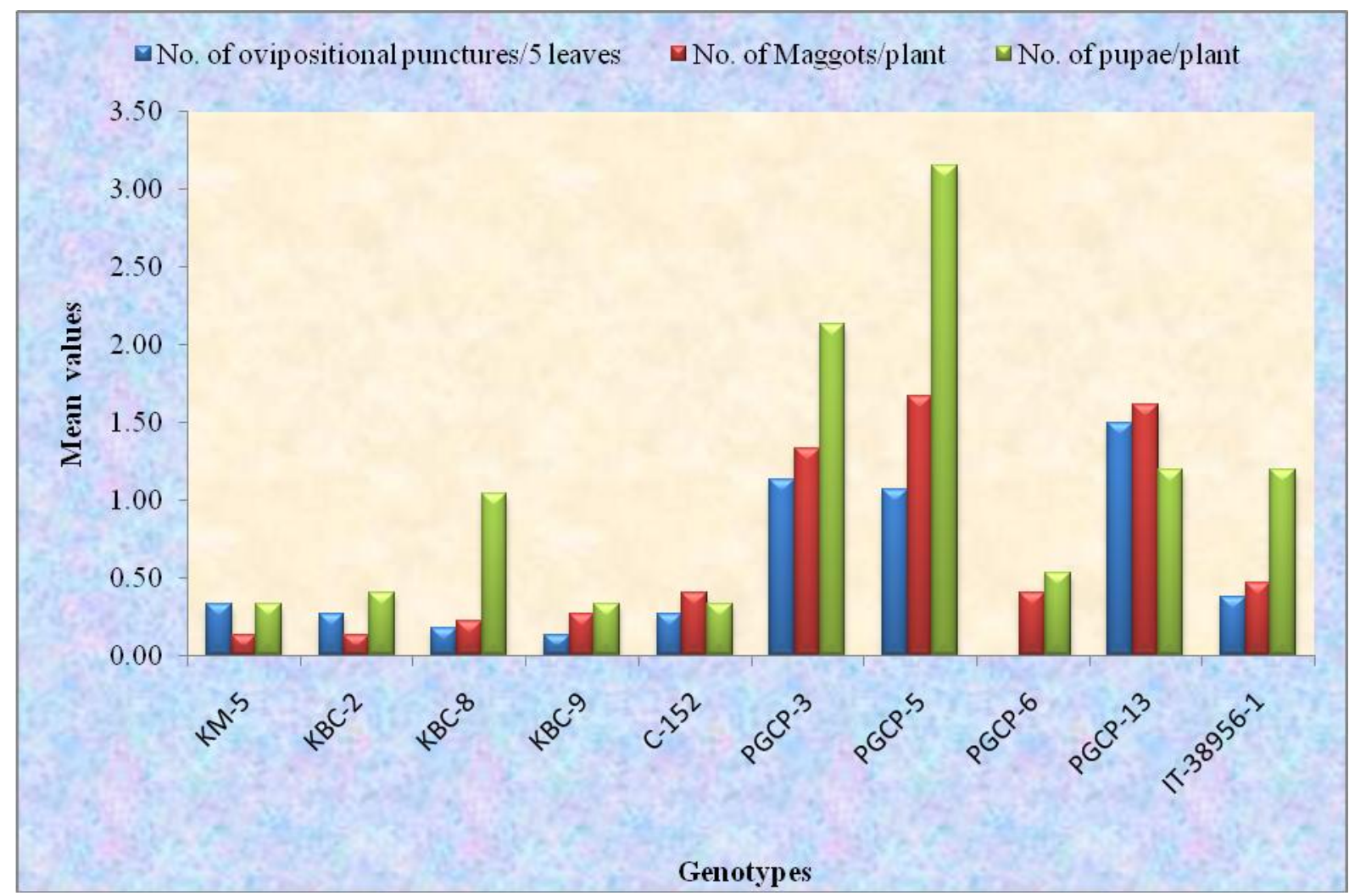


Fig.3 Per cent tunnelling in cowpea genotypes

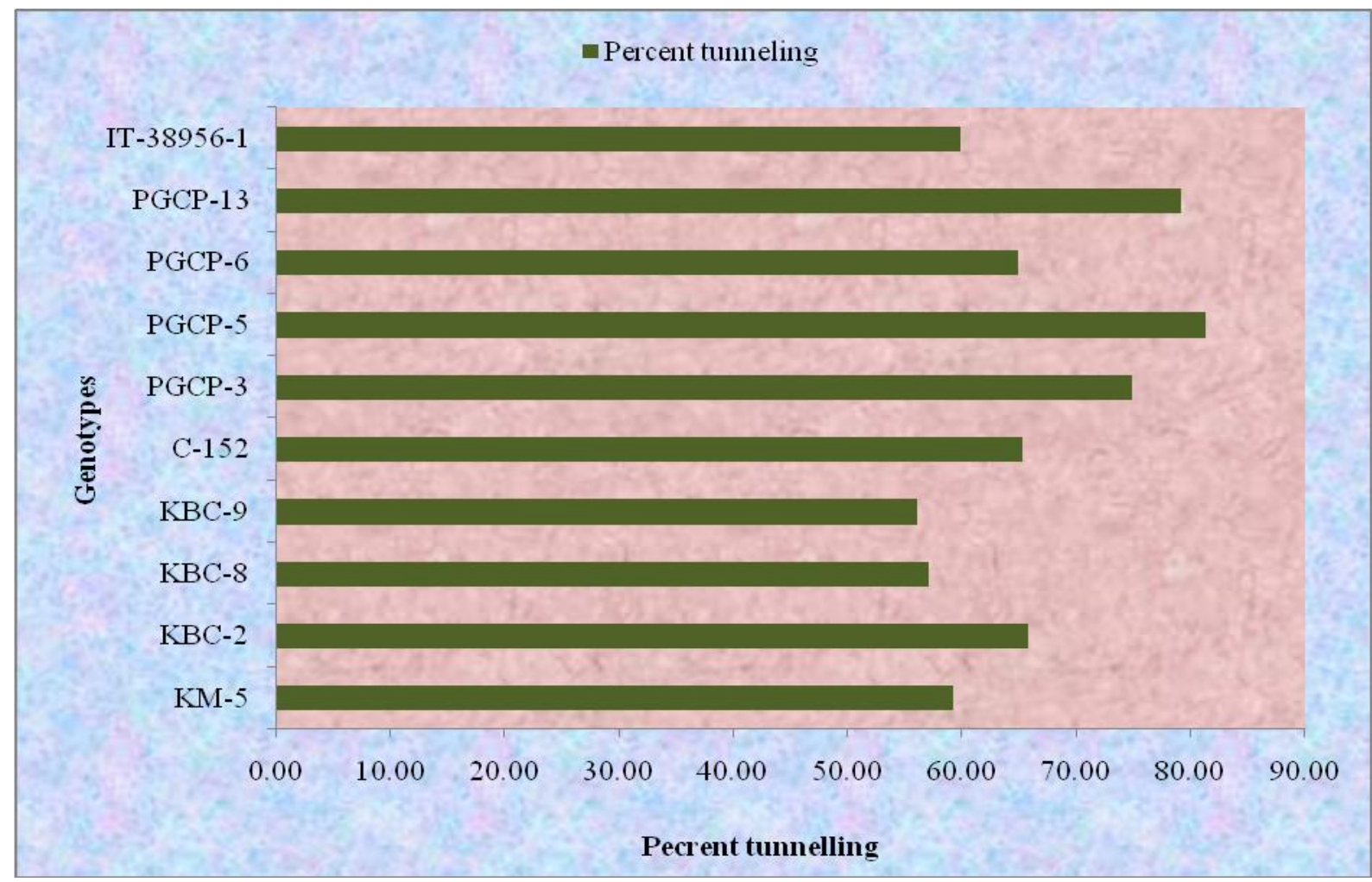

The number of ovipositional punctures were significantly lowest in PGCP - 6, KBC - 9, $\mathrm{KBC}-8, \mathrm{KBC}-2$ where highest number were seen in PGCP - 13 and PGCP - 3. The number of maggots punctures were significantly lowest in $\mathrm{KM}-5, \mathrm{KBC}-2$, KBC -8, KBC -9 , whereas PGCP - 13, PGCP -5 and PGCP - 3 has more number of maggots. The pupal population were significantly lowest in $\mathrm{KM}-5, \mathrm{KBC}-9$, C 152 and $\mathrm{KBC}-2$. In PGCP - 5 and PGCP -3 highest number of pupae were observed. The tunnel length was significantly lower in $\mathrm{KBC}$ $-8, \mathrm{KBC}-9$ and $\mathrm{C}-152$ and significantly higher in PGCP - 13 and PGCP - 5. Further significantly highest seed yield recorded in PGCP $-6, \mathrm{KBC}-2, \mathrm{KBC}-8, \mathrm{KM}-5$ and KBC -9 (Fig. 1-3; Table 2). Present findings are similar with those of talekar and tengkana (1993) where in out of ten entries six or seven entries were moderately resistant to stem fly. There exist significant variations in the different cowpea genotype studied with respect to agronomic and pest damage traits. Selection based on the rank summation index calculated identified two top-ranking lines PGCP - 13 and KBC - 2 therefore could be recommended for testing on farmer's field since they could be used to overcome the challenges faced by farmer.

\section{References}

Attle, A.A., Elihenneidy, A.H. and El-Kady, E.A. 1987. Studies on the aphid, Aphis craccivora in Egypt. Bull de la Societe Entomold' Egypte. 66:319-324.

Banks, C.J. 1957. The behaviour of individual conccinellid larvae of plants. British Journal of Animal Behaviour. 5:12-24.

Bell charles, R., 1980. Studies on the resistance in cowpea, Vigna unguiculata (L.) Walp. to the aphid Aphis craccivora Koch. M.Sc. (Agri.) Thesis, 
Tamil Nadu. Agric. Univ., Coimbatore, Tamil Nadu, (India).

Chiang, H. S. and Talekar, N. S., 1980. Identification of sources of resistance to the beanfly and two other agromyzid flies in soybean and mungbean. J. Econ. Ent., $73: 197$ - 199.

Dayakar, S., Arjuna rao, P. and Tirumala rao, K., 1995. Effect of organic and inorganic sources of $\mathrm{N}$ and $\mathrm{P}$ and certain insecticides on the buildup of pod borers on pigeonpea. The Andhra Agric. J., 42(4): 14-17.

Devaki, K., Muralikrishna, T., Ramakrishna rao, A., Ramaiah, M., Prasanthi, L. and Raja reddy, K., 2011. Management of pod sucking bug complex in cowpea, Ann. Pl. Protec. Sci., 19(2): 451-508.

Dhanorkar, B. J., and Daware, D. G., 1980. Differences in number of aphids found on lines of Cowpea in a replicated trail. Trop. Grain Legume Bull., 10: 3-4.

Ehlers, J., and Hall, A. 1997. Cowpea (Vigna unguiculata L. walp). Field Crops Research, 53: 187-204.

Gomez Souza. J., Oliver Diaz, I., Espinosa Alvarez, L. and Gonzalez Perez, M. 2007. Apuntessobre Aphis craccivora Koch (Homoptera: Aphididae). Centro Agricola. 34:87-88.

Hanchinal, S.G., Patil, B., Bheemanna, M. and Hosamani, A.C. 2010. Population dynamics of mealy bug, Phenacoccuss olenopsis Tinsley and its natural enemies on Bt. cotton. Karnataka Journal of Agricultural Sciences, 23:137-39.

Hasen, H.R., Ahmad, M., Rahman, M.H. and
Haque, M.A. 2009. Aphid incidence and its correlation with different environmental factors. Journal of Bangladesh Agricultural University, 7:15-18.

Karungi, J., Adipala, E., Kyamangyawa, S., Ogenga-Latigo, M., Oyobo, N. and Jackai, L. 2000. Pest management in Cowpea. Part 2. Integrating planting time, plant density and insecticide application for management of cowpea field insect pest in Eastern Uganda. Crop Protection. 19:237-245.

Kataria, R., and Kumar, D. 2012. Occurrence and Infestation level of sucking pests: Aphids on various host plants in Agricultural fields of Vadodara, Gujarat (India). IJSRP 2: 1-6.

Kataria, R., and Kumar, D. 2013. On the Aphid-ant association and its relationship with various host plants in the Agro-ecosystems of Vadodara, Gujarat, India. Halteres 4:25-32.

Pai, K. M., 1990. Incidence of insect pests in early variety of cowpea, Vigna unguiculata (L.) Walp. M.Sc. (Agri.) Thesis, Konam Krishi Vidyaeet, Dapoli, Maharashtra, (India).

Radha, R., 2013. Comparative studies on the Effectiveness of Pesticides for Aphid control in Cowpea. Research. Journal of Agriculture and Forestry Sciences. 1: 17.

Singh, S. R., 1977. Cowpea cultivars resistant to insect pests in world germplasm collection. Tropical Grain Legume Buletin, 9:3-7.

\section{How to cite this article:}

Mantesh Soratur, K.S. Jagadesh, D. Devika Rani, T.G. Avinash and Shiva Murthy Naik. 2018. Reaction of Cowpea Genotypes for Stemfly Ophiomyia phaseoli (Tryon) Diptera: Agromyzidae Infestation. Int.J.Curr.Microbiol.App.Sci. 7(03): 3558-3564. doi: https://doi.org/10.20546/ijcmas.2018.703.409 